\title{
0-12 Aylık Bebeği Olan Ebeveynlerin Bebek Bakımına İlişkin Geleneksel Uygulamaları
}

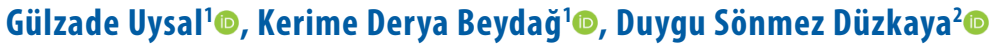

'Okan Üniversitesi, Sağlık Bilimleri Fakültesi, Hemşirelik Bölümü, Hemşirelik, İstanbul, Türkiye 2̇istanbul Üniversitesi İstanbul Tıp Fakültesi, Hemşirelik Hizmetleri Müdürlüğü, Hemşirelik, İstanbul, Türkiye

Gülzade Uysal, Doç. Dr. Kerime Derya Beydağ, Doç. Dr. Duygu Sönmez Düzkaya, Doç. Dr.

Iletişim:

Doç. Dr. Gülzade Uysal

Okan Üniversitesi, Sağlık Bilimleri Fakültesi, Hemşirelik Bölümü, Hemşirelik, İstanbul, Türkiy Tel: +905052520682

E-Posta: gulzade.uysal@okan.edu.tr

Gönderilme Tarihi : 10 Ağustos 2017

Revizyon Tarihi : 20 Eylül 2017

Kabul Tarihi : : 01 Ekim 2017
ÖZET

Amaç: Bu çalışma, 0-12 aylık bebeği olan ebeveynlerin bebek bakımına ilişkin geleneksel uygulamalarını belirlemek amacıyla gerçekleştirilmiştir.

Gereç ve Yöntem: Çalışma tanımlayııı ve kesitsel olarak planlanmış olup veriler Eylül 2015- Aralık 2015 tarihleri arasında Tuzla'da bir aile sağlığı merkezinde toplanmışıı. Çalışmanın evrenini son bir yılda aile sağıı̆ı merkezine kayıtlı 0-12 aylık 328 bebeğin annesi oluşturmuştur. Çalıșmaya katılmaya istekli olan 215 anne $(\% 65,5)$ örnekleme dahil edilmiștir.

Bulgular: Bebeklerin yaş ortalaması 6,25 $\pm 0,24$ aydır. Bebeklerin doğum haftası ortalaması $38,17 \pm 0,19$ hafta olup $\% 52,6$ 'sı kızdır. Çalışmaya katılan annelerin yaş ortalaması $28,74 \pm 0,37$ 'dir. Annelerin $\% 75,3$ 'ü bebek bakımına ilişkin bilgi aldığını, \%79'u bilgiyi hemşire/ebeden aldığını ve $\% 50,6$ 'sı aldığı bilgiyi yeterli bulduğunu ifade etmiştir. Araştırmaya katılan annelerin \% $\% 0^{\prime}$ i bebeğini tuzladığını, \%62,3'ü ilk ağız sütünü dıșarı boşalttı̆ğını, \%6'sı ise bebeğin altına höllük koyduğunu ifade etmișțir. Annelerin \%56,7'si bebeğin göbeği çabuk düssün diye kolonya, \%30,7'si ise zeytinyağı sürdüğünü belirtmiştir. Annelerin $\% 5,1$ 1i pamukçuğu kuru bezle sildiğini, \%34,4'ü pişikte bebeğin altını yıkadığını, \%5,6'sı ise katı yağ sürdüğünü söylemiştir. Annelerin \%48,8'i bebeğini kundak yaptığıı, \%14,9'u bebeğini al basmasından korumak için iki kırklı kadının birbirini ziyarete gitmediğini belirtmişlerdir.

Sonuç: Araştırmaya katılan annelerin çoğunluğunun bebek bakımına ilişkin farklı geleneksel uygulamaları kullanmayı sürdürdükleri görülmektedir. Bu sonuçlar doğrultusunda sağık profesyonelleri tarafından annelerin yenidoğan bakımına ilişkin uygulamalar konusunda bilgilendirilmesi önerilebilir.

Anahtar sözcükler: Bebek bakımı, geleneksel uygulamalar, ebeveyn

\section{TRADITIONAL PRACTICES ON BABY CARE IN PARENTS WITH 0-12 MONTHS BABIES}

\section{ABSTRACT}

Purpose: This study has been conducted in order to determine the traditional practices in regard to infant care of parents with infants between the ages of $0-12$ months.

Materials and Methods: The study was planned as a descriptive cross-sectional study and data were collected using a random sampling method from a family health center in Tuzla between September 2015-December 2015. The universe of the study consisted of 328 infants between the ages of 0-12 months who were registered in a family health center last year. 215 parents $(65.5 \%)$ who were willing to participate in the study were included in the sample.

Findings: The average age of the infants who were included in the study was $6.25 \pm 0.24$ months. The mean of the infants' birth week was $38.17 \pm 0.19$ weeks and $52.6 \%$ of them were baby girls (or females). The average maternal age was $28.74 \pm 0.37 .75 .3 \%$ of the mothers expressed that they got information(were educated) about infant care, $79 \%$ of them expressed that they got information from nurses/midwives and $50.6 \%$ of them expressed that they found the information they learned useful and satisfactory. $80 \%$ of the participating mothers in the study expressed that they salted????! their infants, $62.3 \%$ of them expressed that they emptied the first colostrum. $6 \%$ of them expressed that they put hollum?!??? under their infants. $56.7 \%$ of mothers expressed that they used cologne?!??? and $30.7 \%$ of them expressed that they used olive oil to make the umbilical stump fall off quickly. $5.1 \%$ of the mothers expressed that they wiped the aphtha?!???! (ulcer) with a piece of dry cloth , 34.4\% of them expressed that they washed(bathed/ showered) their infants and $5.6 \%$ of them expressed that they oiled their infants with shortening(in a short time/shortly)???? when they had a rash. $48.8 \%$ of mothers expressed that they swaddled their infants, $14.9 \%$ of them expressed that they did not visit another woman who gave birth within forty days to protect their infants from incubi. (the plural form of "incubus")

Conclusion: It has been observed that the majority of the participating mothers continue to use different traditional practices regarding infant care. In the light of these results, it can be suggested by health professionals to inform the mothers about the applications of infant care.

Keywords: Infant care, traditional practices, parents 
G elenekler, kültürel miraslar, alışkanlıklar, bilgiler, töreler ve davranışlar kuşaktan kuşağa aktarılmaktadır. İnsanların sağlıkla ilgili inanç ve uygulamaları, içinde yaşadığı toplumun kültürünün bir parçasını oluşturmaktadır $(1,2)$. Toplumun kültürel değerleri, gelenekleri, tutum, inanç ve davranışları bireylerin yaşam şeklini dolayısıyla sağlık koşullarını etkilemektedir. Bireyler sağlık sorunlarını ailelerinden görmüş oldukları geleneksel uygulamalarla çözmeye çalışmaktadırlar $(2,3)$. Geleneksel uygulamalara başvurma nedenleri arasında, anneler için; doğum sonu dönemde verilen bakımın yetersizliği, aile büyüklerinin baskısı, doğum sonu dönemde görülen sorunları normal bir durum gibi algılama, kadının toplumdaki statüsü, ekonomik yetersizlikler, sağlık merkezlerinin uzak olması, dini inançlar, sağlık personeline güvenmeme ve sağlık güvencesinin olmaması sayılabilir (1-5).

Geleneksel sağlık uygulamalarının bazıları akılcı, bazıları ise oldukça mantıksız, insan sağlığına zarar verebilen ve yaşam kalitesini olumsuz etkileyebilen uygulamalardır $(6,7)$. Doğum sonu dönemde yapılan ve özellikle sağlık açısından zararlı olan geleneksel uygulamalar bebeğin iyi olma halini etkilemektedir. Örneğin bebeğin doğum sonu hemen tuzlanması bebeğin hassas olan cildinin etkilenmesine, sıkı kundak yapılması bebekte kalça çıkığı riskine, höllüğe yatırılması ise bebeğin tetanos olmasına neden olabilen uygulamalardır (6-11).

Bebek bakımında yapılan geleneksel uygulamalara ilişkin son dönemde yapılan çalışmalarda, geleneksel uygulamaların yaygın olarak kullanıldığı görülmektedir. Çocuk sağıı̆ını etkileyen geleneksel uygulamaların bilinmesi, bunlardan zararlı olanların ortaya çıkarılması ve yok edilmeye çalışılması, sürdürülmesinde sakınca olmayanların ise korunması ve kültürel özellikler ile geleneklere bir anlamda sahip çıkılması oldukça önemlidir (6-15).

Hemşireler özellikle bireylerin kültürel inanç ve uygulamalarının sağlığa yansımaları boyutunda dikkatli olmalıdır. Toplumun sağlıkla ilgili davranışlarını geliştirebilmek için sağlık çalışanlarına düşen görev ve yanlış olan uygulamaların düzeltilmesine yönelik çalışmalar da bulunmaktır $(13,15)$.

Bu çalışma, 0-12 aylık bebeği olan ebeveynlerin bebek bakımına ilişkin geleneksel uygulamaları belirlemek amacıyla gerçekleştirilmiştir.

\section{Gereç ve yöntem}

Tanımlayıcı ve kesitsel olarak planlanmış olan araştırmanın verileri, Eylül 2015- Aralık 2015 tarihleri arasında Tuzla'da rastgele örneklem yöntemi ile seçilmiş bir aile sağlığı merkezinde toplanmıştır.
Çalışmanın evrenini son bir yılda aile sağlığı merkezine kayıtlı olan 0-12 aylık 328 bebeğin annesi oluşturmuştur. Çalışmanın örnekleminin belirlenmesinde evrendeki birey sayısı bilindiğinde kullanılan formülden yararlanılmış olup örneklem büyüklüğü 185 kişi olarak hesaplanmıştır. Çalışmaya katılmaya istekli olan, türkçe konuşup anlaşabilen,okuma-yazma bilen ve verilerin toplanma süresinde ulaşılan 215 anne çalışmaya dahil edilmiştir.

Veriler literatür doğrultusunda oluşturulan bebek ve ailesine ilişkin sosyo-demografik bilgileri ve bebek bakımına ilişkin geleneksel uygulamaları sorgulayan soru formu ile toplanmıştır. Veriler SPSS 21.0 paket programında, sayı yüzdelik hesapları ile değerlendirilmiştir. Çalışmadan elde edilen veriler, çalışmanın yapıldığı bölgedeki aile sağlığı merkezine kayıtlı 0-12 aylık bebeği olan anneler ile sınırlıdır.

\section{Bulgular}

Araştırmaya katılan bebeklerin yaş ortalaması $6,25 \pm 0,24$ ay, boy ortalaması $65,5 \pm 0,55 \mathrm{~cm}$ ve kilo ortalaması 7,827 $\pm 433,90$ gramdır. Bebeklerin doğum

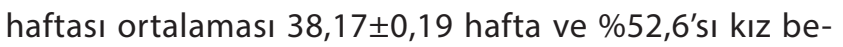
bektir. Bebeklerin \%55,3'ü normal doğum ile dünyaya gelmiştir. Çalışmaya katılan annelerin yaş ortalaması $28,74 \pm 0,37, \% 63,3$ 'ü ev hanımı, \%40,5'i ilkokul mezunudur. \%62,8'inin geliri giderine eşit ve $\% 87,4$ 'ü de çekirdek aile tipindedir (Tablo 1).

Annelerin \%75,3'ü bebek bakımına ilişkin bilgi almış olup, bunların \%50,6'sı aldığı bilgiyi yeterli bulmakta ve \%79’u bilgiyi hemşire/ebeden aldığını belirtmektedir. Annelerin \%65,6'sı herhangi bir sağlık sorunu olduğunda, sorunu geleneksel uygulamalar ile çözmeye çalıştığını ifade etmiş ve yalnızca \%7,4'ü geleneksel uygulamaları sağlık sorunlarını çözmede ve önlemede hiç önemli bulmadıklarını ifade etmişlerdir (Tablo 2).

Çalışmaya katılan annelerin \%80'i bebeğini tuzladığını, \%62,3'ü ilk ağız sütünü dışarı boşalttığını, \%6'sı bebeğin altına höllük koyduğunu ifade etmiştir. Annelerin \%56,7'si bebeğin göbeği çabuk düşsün diye kolonya sürdüğünü, \%30,7'si zeytinyağı sürdüğünü, \%12,6'sı göbeğe demir para koyduğunu belirtmiştir.

Annelerin \%60,9'u bebeği sarılık olmasın diye yumurta sarısı ile yıkadığını, \%27'si maden suyu içirdiğini, \%12,1'i sarı örtü ile üzerini örttüğünü söylemiştir. Annelerin \%5,1'i pamukçuğu kuru bezle sildiğini, \%4,7'si karbonatlı su ile bebeğin ağzını sildiğini belirtmiştir. Pişiği olan bebeklere 
yapılan uygulamalar değerlendirildiğinde; annelerin \%34,4'ü bebeğin altını yıkadığını, \%19,5'i krem sürdüğünü, \%9,3'ü pudra sürdüğünü ve \%5,6'sı katı yağ sürdüğünü söylemiştir.

Tablo 1. Bebek ve anneye ilişkin tanıtıcı bilgiler $(n=215)$

\begin{tabular}{|c|c|c|}
\hline Değişkenler & $n$ & $\%$ \\
\hline $\begin{array}{l}\text { Bebeğin cinsiyeti } \\
\text { KIz } \\
\text { Erkek }\end{array}$ & $\begin{array}{l}113 \\
102\end{array}$ & $\begin{array}{l}52,6 \\
47,4\end{array}$ \\
\hline $\begin{array}{l}\text { Doğum şekli } \\
\text { Normal doğum } \\
\text { Sezeryan }\end{array}$ & $\begin{array}{c}119 \\
96\end{array}$ & $\begin{array}{l}55,3 \\
44,7\end{array}$ \\
\hline $\begin{array}{l}\text { Anne mesleği } \\
\text { Ev hanımı } \\
\text { Diğer (işçi, memur, serbest meslek) }\end{array}$ & $\begin{array}{c}136 \\
79\end{array}$ & $\begin{array}{l}63,3 \\
36,7\end{array}$ \\
\hline $\begin{array}{l}\text { Anne eğitim durumu } \\
\text { Okur-yazar } \\
\text { Illköğretim mezunu } \\
\text { Orta öğretim mezunu } \\
\text { Üniversite mezunu }\end{array}$ & $\begin{array}{l}18 \\
87 \\
54 \\
59\end{array}$ & $\begin{array}{r}7,0 \\
40,5 \\
25,1 \\
27,4\end{array}$ \\
\hline $\begin{array}{l}\text { Ailenin ekonomik durumu } \\
\text { Gelir giderden az } \\
\text { Gelir gidere eşit } \\
\text { Gelir giderden fazla }\end{array}$ & $\begin{array}{c}54 \\
135 \\
26\end{array}$ & $\begin{array}{l}25,1 \\
62,8 \\
12,1\end{array}$ \\
\hline $\begin{array}{l}\text { Aile tipi } \\
\text { Çekirdek aile } \\
\text { Geniş aile }\end{array}$ & $\begin{array}{c}188 \\
27\end{array}$ & $\begin{array}{l}87,4 \\
12,6\end{array}$ \\
\hline Anne yaş ortalaması & \multicolumn{2}{|c|}{$28,74 \pm 0,37$ yaş } \\
\hline Doğum haftası ortalaması & \multicolumn{2}{|c|}{$38,17 \pm 0,19$ hafta } \\
\hline Bebek yaş ortalaması & \multicolumn{2}{|c|}{$6,25 \pm 0,24$ ay } \\
\hline Bebek boy ortalaması & \multicolumn{2}{|c|}{$65,5 \pm 0,55 \mathrm{~cm}$} \\
\hline Bebek kilo ortalaması & \multicolumn{2}{|c|}{$7827,62 \pm 433,90 \mathrm{gr}$} \\
\hline
\end{tabular}

Tablo 2. Annelerin geleneksel uygulamaya ilişkin bilgiler $(n=215)$

\begin{tabular}{lcc} 
Değişkenler & $\boldsymbol{n}$ & $\%$ \\
\hline Bebek bakımı ile ilgili bilgi alma durumu & & \\
Alan & 162 & 75,3 \\
Almayan & 53 & 24,7 \\
Bilgiyi yeterli bulma durumu ( $\mathbf{n}=162)$ & & \\
Yeterli & 82 & 50,6 \\
Kısmen yeterli & 76 & 46,9 \\
Yetersiz & 4 & 2,5 \\
Bebek bakımı ile ilgili bilgiyi & & \\
kimden aldığı (n=162) & & \\
$\begin{array}{l}\text { Hemşire/ ebe } \\
\text { *Diğer }\end{array}$ & 128 & 79,0 \\
Sağlık sorunlarında geleneksel & 34 & 21,0 \\
uygulamalara başvurma durumu & & \\
Başvuran & & \\
Başvurmayan & 141 & 65,6 \\
\hline
\end{tabular}

${ }^{*}$ Doktor, arkadaş, aile büyükleri, internet, dergi, kitap
Annelerin \%48,8'i bebeğini kundak yaptığını belirtmiştir. Kundak yapma nedenleri sorgulandığında; \%9,8'i beli batmasın diye, $\% 6$ 'sı bacakları düzgün olsun diye ve $\% 4,2$ 'si rahat uyusun diye kundak yaptığını ifade etmiştir. Annelerin \%14,9'u bebeğini al basmasından korumak için iki kırklı kadının birbirini ziyarete gitmediğini ve bebeği doğumdan 7 gün, 20 gün ve 40 gün sonra yıkadıklarını söylemiştir. Bebek al basması olmuşsa \%28,4'ü bebeğin yüzüne kırmızı tülbent örtüklerini, \%23,7'si hocaya okuttuklarını, \%21,4'ü muska kullandıklarını belirtmiştir (Tablo 3).

Tablo 3. Annelerin bebeğe uyguladıkları geleneksel yöntemler $(n=215)$

\begin{tabular}{|c|c|c|}
\hline Değişkenler & Sayı & üzde (\% \\
\hline $\begin{array}{l}\text { İlk ağız sütünü boşaltma durumu } \\
\text { Boşaltan } \\
\text { Boşaltmayan }\end{array}$ & $\begin{array}{c}134 \\
81\end{array}$ & $\begin{array}{l}62,3 \\
37,7\end{array}$ \\
\hline $\begin{array}{l}\text { Bebeğin altına höllük koyma durumu } \\
\text { Koymayan } \\
\text { Koyan }\end{array}$ & $\begin{array}{c}202 \\
13\end{array}$ & $\begin{array}{c}94,0 \\
6,0\end{array}$ \\
\hline $\begin{array}{l}\text { Bebeğini tuzlama durumu } \\
\text { Tuzlamayan } \\
\text { Tuzlayan }\end{array}$ & $\begin{array}{c}43 \\
172\end{array}$ & $\begin{array}{l}20,0 \\
80,0\end{array}$ \\
\hline $\begin{array}{l}\text { Göbeği çabuk düşsün diye yapılan uygulamalar } \\
\text { Göbeğe kolonya sürmek } \\
\text { Göbeğe zeytinyağı sürmek } \\
\text { ^Diğer }\end{array}$ & $\begin{array}{c}122 \\
66 \\
27\end{array}$ & $\begin{array}{l}56,7 \\
30,7 \\
12,6\end{array}$ \\
\hline $\begin{array}{l}\text { Bebek sarılık olmasın diye yapılan uygulamalar } \\
\text { Yumurta sarısı ile yıkamak } \\
\text { Maden suyu içirmek } \\
\text { Sarı örtü örtmek }\end{array}$ & $\begin{array}{c}131 \\
58 \\
26\end{array}$ & $\begin{array}{l}60,9 \\
27,0 \\
12,1\end{array}$ \\
\hline $\begin{array}{l}\text { Pamukçukta yapılan uygulamalar } \\
\text { Doktora götüren } \\
\text { Kuru bezle silen } \\
\text { Karbonatlı su ile silen }\end{array}$ & $\begin{array}{c}194 \\
11 \\
10\end{array}$ & $\begin{array}{c}90,2 \\
5,1 \\
4,7\end{array}$ \\
\hline $\begin{array}{l}\text { Pişikte yapılan uygulamalar } \\
\text { Bebeğin altını yıkamak } \\
\text { Krem sürmek } \\
\text { Pudra sürmek } \\
\text { Katı yağ sürmek } \\
\text { Doktora götürmek }\end{array}$ & $\begin{array}{l}74 \\
42 \\
20 \\
12 \\
67\end{array}$ & $\begin{array}{c}34,4 \\
19,5 \\
9,3 \\
5,6 \\
31,2\end{array}$ \\
\hline $\begin{array}{l}\text { Bebeği kundak yapma durumu } \\
\text { Yapmayan } \\
\text { Beli batmasın diye yapan } \\
\text { Bacakları düzgün olsun diye } \\
\text { Rahat uyusun diye } \\
\text { **Diğer }\end{array}$ & $\begin{array}{c}110 \\
21 \\
13 \\
9 \\
62\end{array}$ & $\begin{array}{c}51,2 \\
9,8 \\
6,0 \\
4,2 \\
28,8\end{array}$ \\
\hline $\begin{array}{l}\text { Al basmasından korumak için yapılan uygulamalar } \\
\text { İki kırklı kadının birbirini ziyarete gitmemek } \\
\text { Bebeği doğumdan } 7,20 \text { ve } 40 \text { gün sonra yıkamak } \\
\text { Bebeği yalnız bırakmamak } \\
\text { Bebeğin odasında kırk gün ışık yakmak } \\
\text { Herhangi bir şey yapmamak }\end{array}$ & $\begin{array}{c}32 \\
32 \\
19 \\
24 \\
108\end{array}$ & $\begin{array}{c}14,9 \\
14,9 \\
8,8 \\
11,2 \\
50,2\end{array}$ \\
\hline $\begin{array}{l}\text { Albasması olmuşsa yapılan uygulamalar } \\
\text { Bebeğin yüzüne kırmızı tülbent örtmek } \\
\text { Hocaya okutmak } \\
\text { Muska okutmak } \\
\star \star \star \text { Diğer }\end{array}$ & $\begin{array}{l}61 \\
51 \\
46 \\
57\end{array}$ & $\begin{array}{l}28,4 \\
23,7 \\
21,4 \\
26,5\end{array}$ \\
\hline
\end{tabular}

*Göbeğe bezden teker yapıp koymak, demir para koymak

**Bebek sert olsun diye, sıcak kalsın diye, aile büyüklerinden öyle öğrendikleri için ***Kurşun döktürmek, dua etmek, sarı örtü örtmek 


\section{Tartışma}

Bebek bakımına ilişkin geleneksel uygulamaları belirlemek amacıyla 0-12 aylık bebeği olan ebeveynler ile gerçekleştirilen bu araştırmada, annelerin \%65,6'sı herhangi bir sağlık sorunu olduğunda sorunu geleneksel uygulamalar ile çözmeye çalıştı̆ı̆ını ifade etmiş ve sadece $\% 7,4$ 'ü geleneksel uygulamaları sağlık sorunlarını çözmek için kullanmadıklarını belirtmiştir (Tablo 2). Eğri ve Gölbaşı (2007) Tokat'da yaptığı çalışmada kadınların \%80'inin doğum sonu dönemde bebek bakımına yönelik geleneksel uygulama yaptığını, Çalışkan ve Bayat'ın (2011) Kapodokya'da yaptıkları çalışmada annelerin \%83,7'sinin geleneksel uygulama kullandıkları, Çetinkaya ve arkadaşlarının (2008) Manisa'da yaptıkları çalışmada kadınların \%92,8'inin doğum sonu dönemde yenidoğan sağlığı ile ilgili en az bir geleneksel uygulama yaptığı, Sis Çelik ve arkadaşlarının (2012) Erzurum'da yaptıkları çalışmada kadınların \%92,8'inin bebek bakımına yönelik geleneksel uygulama yaptığı ve Çınar ve ark. (2015) çaIışmasında, bebek bakımında annelerin \%68,6'sı geleneksel uygulama yaptıkları belirlenmiştir $(4,6,12,13,16)$. Molu'nun (2011) yaptığı çalışmada ise, kadınların \%15,2'sinin herhangi bir sağlık sorunu yaşadıklarında bildiği bazı geleneksel uygulamalarla sorunu çözmeye çalıştıkları ve $\% 8,6$ 'sı için geleneksel uygulamaların önemsiz olduğu bulunmuştur (27). Literatürde de görüldüğü gibi ülkemizde geleneksel uygulamaların ebeveynler tarafından sıklıkla kullanıldığı söylenebilir.

Araştırmaya katılan annelerin \%62,3'ü ilk ağız sütünü dışarı boşalttığını belirtmiştir (Tablo 3). Biltekin ve ark.'nın (2004) çalışmasında annelerin \%50'sinin kolostrumu sağıp attıkları belirlenmiştir (10). Uganda'da anneler bebeklerine hastalanabileceği düşüncesiyle kolostrumu vermemektedirler (17). Seviğ ve Tanrıverdi (2011), İspanya'daki annelerin de kolostrumu kötü ya da kirli olduğu için bebeklerine vermediklerini belirtmiştir (2). Öte yandan Gölcük'ün (2014) çalışmasında, ilk ağız sütünü boşaltma oranı \%14,4; Molu'nun (2011) çalışmasında \%14,9 olarak bulunmuştur $(26,27)$. Annenin ilk sütü olan kolostrum protein, mineral ve vitaminlerden zengin bir içeriğe sahiptir. Bebeğin doğumdan sonra annenin ilk sütü olan kolostrumu alması immun sisteminin gelişmesinde öenmli rol oynamaktadır. Bebeğe kolostrumun verilmemesi enfeksiyonlara karşı güçlü bir bariyer olan immünoglobulini bebeğin alamamasına ve bebekle anne arasındaki etkileşimin geç başlamasına neden olmaktadır (18). Kundaktaki bebeklere bez yerine elenmiş, kuru ince toprak konmasına höllük denir. Özellikle idrarı emmesi nedeniyle pişik oluşumunu önlemek amacıyla kullanılmaktadır. Höllük, tetanoz gibi bulaşıı hastalıkların yayılması, bebeğin cildine zarar verebileceği ve hatta bebeğin ölçesine neden olabileceği için oldukça risklidir (27). Araştırmada annelerin \%6'sının höllük uyguladığı belirlenmiştir (Tablo 3). Diğer çalışmalarda höllüğün kullanımına ilişkin veriler yörelere göre farklılık gösterse de, Malatya'da yapılan bir çalışmada annelerin \%25'inin (26), Afyon'da yapılan başka bir çalışmada ise annelerin \%1'inin höllük kullandığı bildirilmiştir (27). Araştırmanın yapıldığı bölge Türkiye'nin bir çok yerinden göç almakta olan bir bölgedir. Bu uygulamanın olumsuz sonuçlarına rağmen bugün hala kullanılıyor olması oldukça çarpıcıdır.

Araştırma kapsamına alınan annelerin \%80'i bebeğini tuzladığını belirtmiştir (Tablo 3). Ülkemizde yapılan benzer araştırmalardaki sonuçlar incelendiğinde; Arısoy ve ark'nın (2014) Karaman'da yaptıkları çalışmada \%25,7, Çetinkaya ve ark.'nın (2008) Manisa' da yaptıkları çalışmada \%74,2, Dinç'in (2005) Şanlıurfa'da yaptığı çalışmada \%39, Eğri ve Gölbaşı́nın (2007) Tokat'ta yaptıkları çalışmada \%64, Şenol ve ark.'nın (2004) Kayseri'de yaptıkları çalışmada \%44,4, Biltekin ve ark.'nın (2004) İzmir'de yaptıkları çalışmada \%76,5, Çalışkan ve Bayat'ın (2011) Nevşehir'de yaptıkları çalışmada \% 17,5 , Sis Çelik ve ark.'nın (2012) Erzurum'da yaptıkları çalışmalarında \%14,4, Sülü Uğurlu'nun Ödemiş'te yaptığı çalışmada \%67,3, Yalçın'ın (2012) Karaman'da yaptığı çalışmada \%58,9; Çınar ve ark. (2015) Denizli'de yaptıkları çalışmada \%62,8, Cetişli ve ark. (2014) Ege bölgesinde yaptıkları çalışmada \%50,1, Işık ve ark.'nın (2010) Mersin'de yaptıkları çalışmada \%86,5, Lafçı ve Erdem'in (2014) Gaziantep'te yaptığı çalışmasında \%47,3, Gölcük'ün (2014) Malatya'da yaptığı çalışmada $\% 38,3$ ve Molu'nun (2011), Afyon'da yaptığı çalışmada annelerin \%35,6'sının yenidoğanı tuzladığı belirtilmiştir $(3-7,10,12-15,19,20,22,26,27)$. Yenidoğanı tuzlama uygulaması ağrıya, deride kızarıklığa, derinin bütünlüğünün bozulmasına, ayrıca vücuttan sıvı kaybına ve dehidratasyona neden olabileceği için sağlığa zararlı bir uygulamadır $(6,18,21)$. Yenidoğan bebeği tuzlama farklı bölgelerde yapılan çalışmalarla karşılaştıııldığında, oranın \%14-80 arasında değiştiği görülmektedir. İstanbul'da gerçekleştirilen bu araştırmanın sonucunda ise diğer çalışma sonuçlarına göre bebeği tuzlamanın daha sık uygulandığı belirlenmiştir.

Annelerin \%56,7'si bebeğin göbeği çabuk düşsün diye kolonya sürdüğünü, \%30,7'si zeytinyağı sürdüğünü ve $\% 12,6$ 'sı göbeğe demir para koyduğunu belirtmiştir (Tablo 3). Türkiye'nin farklı şehirlerinde yapılan çaış̧malarda da kadınların göbek bakımında zeytin yağı kullanma oranlarının \%20,1 ile \%89,8 arasında olduğu belirlenmiştir $(6,12,15)$. Cetişli ve ark.'nın (2014) yaptıkları 
çalışmanın sonucunda annelerin \%31,2'sinin, Kahriman'ın (2007) Trabzon'da yaptığı çalışmada annelerin \%16,6'sının yenidoğan göbek bakımında zeytinyağı kullanıldığı belirlenmiştir $(19,24)$. Özsoy ve Katabi'nin $(2008)$ yaptıkları çalışmada annelerin \%66,7'sinin göbek bakımı için alkol, tentürdiyot uyguladıklarını, Arısoy ve ark.'nın (2014) Karaman'da yaptıkları çalışmada da annelerin \%82,6'sının göbek bakımında alkol kullandıkları belirlenmiştir $(3,23)$. Göbek kordonunun düşmesine katkı sağlamaya yönelik zeytinyağı ya da başka bir madde sürülmesi gibi geleneksel uygulamalar yenidoğanın hassas olan cildinde tahrişe yol açma ve enfeksiyon, potansiyeli taşımaktadır (19). Sağlıklı bebekler için göbeğin düşene kadar kuru tutulması; risk altındaki yenidoğanlar için ise hastanede kaldığ sürece antiseptik kullanımı önerilmektedir (18).

Annelerin $\% 60,9^{\prime}$ u bebeği sarılık olmasın diye yumurta sarısı ile yıkadığını, \%27'si maden suyu içirdiğini, $\% 12,1$ 'i üstünü sarı örtü ile örttüğünü belirtmiştir (Tablo 3). Bölükbaş ve ark.'nın (2009) çalışmasında, annelerin \%24,6'sının bebeklerine sarı giydirdiği, sık emzirdiği, altın suyunda yıkadığı ve ışık altında bıraktığı belirlenmiştir (11). Yenidoğan sarılığını önlemeye yönelik ülkemizde gerçekleştirilen geleneksel uygulamaların başında sarı yazma örtme geleneği vardır. Çetinkaya ve ark.'nın (2008) yaptıkları çalışmada \%70,7; Dinç'in (2005) çalışmasında \%18.2, Eğri ve Gölbaşı'nın (2007) yaptıkları çalışmada \%73,6, Şenol ve ark.'nın (2004) çalışmasında \%54,5, Çalışkan ve ark. (2011)' nın yaptıkları çalışmada \%48,9, Sis Çelik ve ark.'nın (2012) çalışmasında \%7,2, Yalçın'ın (2012) çalışmasında \%55,3, Çınar ve ark.(2015) çalışmasında \%7,1, Cetişli ve ark.(2014) yaptıkları çalışmada \%61,2, Işık ve ark. (2010) gerçekleştirdikleri çalışmada \%46,1 ve Gölcük'ün (2014) Malatya'da yaptığı çalışmada \%37,2 sıklığında sarılık olmasına önlem olarak yenidoğanın yüzüne sarı yazma örttükleri bildirilmiştir (4-7,12,13,15,16,19,20,26). Molu'nun (2011), Afyon'da yaptığı çalışmada bebeği sarılıktan korumak için en sık yüzüne sarı örtü örttükleri $(\% 48,4)$ ve maden suyu verdikleri $(\% 22,5)$ görülmektedir (27). Bebeğin sağlığı açısından zararı olmayan aileyi psikolojik açıdan rahatlattığı düşünülen sarı giydirmek, altın suyunda yıkamak gibi geleneksel uygulamaları değiştirmek için ısrarcı olmamak yerine ebeveynlerin yeterli ve uygun bilgilendirilmesi önemlidir. Öte yandan bebeğin sağlığını tehdit edebilecek maden suyu içirmek, tuza yatırmak gibi uygulamaların bebeğin sağlığına olumsuz etkileri açıklanarak ebeveynlerin bu uygulamaları yapmaması konusunda uyarılması önemlidir.

Araştırmada ebeveynlerin pamukçuğa ilişkin geleneksel uygulamaları değerlendirildiğinde annelerin $\% 5,1^{\prime} \mathrm{i}$ pamukçuğu kuru bezle sildiğini, \%4,7'si karbonatlı su ile bebeğin ağzını sildiğini belirtmiştir (Tablo 3). Yapılan benzer çalışmalara bakıldığında; Bölükbaş ve ark.'nın (2009) yaptığı çalışmada annelerin \%25,1'inin, Gölcük'ün (2014) çalışmasında, annelerin \%11,8'i, Afyon'da yapılan benzer bir çalışmada da \%57,6'sı ağız bakımında karbonatlı su ile silme yöntemini kullandıkları bildirilmiştir $(11,26,27)$. Öte yandan yapılan benzer çalışmalarda annelerin yarıdan çoğunun bebeğin pamukçuğu için yemek sodası ile silme yöntemini uyguladıkları dikkati çekmektedir $(6,10,16)$. Bununla birlikte yapılan bir çalışmada annelerin $\% 32,5^{\prime}$ inin bebeğinin ağzında pamukçuk olduğunda sağlık kuruluşuna başvurduğu bildirilmiştir (11). Annelerin çoğunluğunun kolay önlenebilir pamukçuğun geçmesi için yemek sodası ve karbonatlı su ile ağız içini temizlemesi modern tıp ve hemşirelik uygulamalarında yaygın kullanılan bir yöntemdir. Ancak halen bikarbonatın pamukçuk bakımında kullanımı tartışmalıdır. Hemşireler ebeveynlere bilgi aktarmadan önce; hem geleneksel hem de bilimsel uygulamaları kanıt temelli sonuçlar doğrultusunda değerlendirmelidir.

Araştırmaya katılan annelerin \%34,4'ü pişik durumunda bebeğin altını yıkadığını, \%31,2'si doktora götürdüğünü, \%19,5'i krem sürdüğünü, \%9,3'ü pudra sürdüğünü ve $\% 5,6$ 'sı katı yağ sürdüğünü ifade etmiştir (Tablo 3 ). Karaman'da yapılan bir çalışma sonuçları incelendiğinde annelerin \%40,3'ü bebeklerini pişikten korumak için pudra döktükleri, \%68'inin bebekleri pişik olduğunda doktorun verdiği kremleri kullandıkları bulunmuştur (15). Çınar ve ark.'nın (2015) Denizli'de yaptıkları çalışmada, annelerin $\% 84,8$ i pişik kremi kullandıklarını, $\% 6,6$ 'sı pudra sürdüğünü, \%5,1'i zeytinyağı sürdüğünü ifade etmiştir (16). Gölcük'ün (2014) Malatya'da yaptığı çalışmada, annelerin en fazla pişik bölgesine krem sürme $(\% 37,8)$, pudra kullanımı $(\% 31,6)$, zeytinyağı $(\% 9,2)$ ve anne sütü $(\% 8,7)$ sürme uygulamalarını kullandıkları belirlenmiştir. (26). Molu'nun (2011) Afyon'da yaptığı çalışmada da pişik bölgesine krem sürme $(\% 51,8)$, bebeği yıkama $(\% 24,9)$, pudra sürme $(\% 17,8)$, bebeği höllüğe yatırma ve zeytinyağı sürme uygulamalarının kullanıldığı belirlenmiştir (27).

Bebeğin kundaklanması ülkemizde çok sık kullanılan geleneksel uygulamalar arasında yer almaktadır. Araştırmaya katılan annelerin \%48,8'inin bebeğini kundakladığı görülmektedir. Kundak yapılmasının nedenleri incelendiğinde ise bebeğin belinin batmaması, bacaklarının düzgün olması ve rahat uyuması için kundak yaptıları belirlenmiştir (Tablo 3). Literatürde bebeklerin kundaklanması ile ilgili bir çok farklı veri olmakla birlikte, ülkemizin farklı bölgelerinde yapılan çalışma sonuçlarına göre kundaklama 
sıklığının \%33,2-\%88,9 arasında değiştiği görülmektedir $(4,5,7,10,11,13,15,22,25-27)$. Kundaklama nedenleri açısından bakıldığında ise; bu araştırmanın sonuçlarına paralel olarak Çetinkaya ve ark. (2008) çalışmasında, annelerin \%60,4'ünün bebeğin kolları ve bacaklarının eğri olmaması için kundakladıklarını belirtmişlerdir (4). Bebeği kundak yapmanın bebek sağlığı açısından bazı sakıncalarının olabileceği ve bebeğin serbest hareket etmesini engellediği düşünüldüğünde annelere yeterli ve doğru bilgi vererek bebeklerini sıkı bir biçimde kundaklamalarının/sarmalarının sakıncaları açıklanmalıdır.

Annelerin \%14,9'u bebeğini al basmasından korumak için iki kırklı kadının birbirini ziyarete gitmediğini ve bebeği doğumdan 7 gün sonra, 20 gün sonra ve 40 gün sonra yıkadıklarını söylemiştir. Eğer al basması olmuşsa, \%28,4'ü bebeğin yüzüne kırmızı tülbent örtüklerini, \%23,7'si hocaya okuttuklarını, \%21,4'ü muska okuttuklarını belirtmiştir (Tablo 3). Cetişli'nin (2014) çalışmasında, araştırmaya katılan kadınlar arasında al basmasını önlemek amacıyla yenidoğanın giysisine/ yatağına dua takma $(\% 67,9)$, lohusa ve yenidoğanı yalnız bırakmama $(\% 66,9)$, başucuna dua ya da ekmek koyma $(\% 56,1)$, yenidoğanı kırk günlük olana kadar adetli kadına göstermeme $(\% 31,8)$ ve lohusa başka bir anne ya da bebeği ile karşılaşmamaya dikkat etme $(\% 30,2)$ gibi uygulamalar yapılmaktadır (19). Gölcük'ün (2014) çalışmasında, annelerin \%42,9'unun bebeği al basmasından korumak için bebeğin başucuna dua ya da ekmek koydukları, \%28,1'inin hiçbir şey yapmadıklarını, $\% 9,2$ 'sinin korunmak için dua okuduğu, kalan \%19,9'unun çeşitli uygulamalar ile bebeklerini korumaya çalıştıkları bildirilmiştir. Bebekteki al basmasını geçirmek için annelerin büyük bir kısmı ne yapacağını bilmemekte olup $(\% 56,1)$,

\section{Kaynaklar}

1. Eğri GB, Konak A. Doğum Sonu Dönem ile İlgili Geleneksel İnanç ve Uygulamalara Dünyadan ve Türkiye'den Örnekler. Journal of World of Turks 2011; 3:143-5.

2. Seviğ Ü, Tanrıverdi G, (eds). Kültürlerarası Hemşirelik. 1. Baskı. İstanbul: İstanbul Tıp Kitabevi; 2011.

3. Arısoy A, Canbulat N, Ayhan F. Karaman İlindeki Annelerin Bebeklerinin Bakımında Uyguladıkları Geleneksel Yöntemler, Anadolu Hemşirelik ve Sağlık Bilimleri Dergisi 2014; 17:23-31.

4. Çetinkaya A, Özmen D, Cambaz S. Manisa'da Çocuğu Olan 15- 49 Yaş Kadınların Doğum Sonu Dönemde Yenidoğan Sağlığı İle İlgili Geleneksel Uygulamaları. Cumhuriyet Üniversitesi Hemşirelik Yüksek Okulu Dergisi 2008;12:39-46.

5. Dinç S. Şanlıurfa Merkezde Bulunan 4 Numaralı Sağlık Ocağına Kayıtı 0- 1 Yaşında Çocuğa Sahip Olan Annelerin Çocuklarının Bakımında Uyguladıkları Geleneksel Uygulamalar. Hemşirelikte Araştırma Geliştirme Dergisi 2005; 1:53-63. bunu \%14,3 ile dua okumak ve ziyarete götürmek izlemektedir. Yine annelerin \%5,1'i bebeğin başucuna Kur'an koyduklarını, kalan \%10,2'lik kısmın ise çeşitli uygulamalar yaptıklarını belirtmiş̧lerdir (26). Molu'nun (2011) çalışmasında, al basmasını geçirmek için kırk banyosu yaptırmak en çok yapılan uygulama olup $(\% 41,1)$, bunu $\% 13,1$ ile bebeğin göğsüne dua koymak izlemektedir (27). Al basmasının inanmalarının modern tıptaki karşıı̆ı̆ "doğum sonrası depresyon" dur. Bu tür geleneksel uygulamaların bilimsel bir kanıt değeri olmamakla birlikte; sağlığa olumsuz bir etkisi de yoktur. Bu nedenle spirituel gereksinimleri karşıladığı düşünüldüğünde anlayışla karşılanabilir.

\section{Sonuç ve öneriler}

Araştırmaya katılan annelerin çoğunluğunun bebek bakımına ilişkin farklı geleneksel uygulamaları kullanmayı sürdürdükleri görülmektedir. Bu sonuçlar doğrultusunda sağlık profesyonelleri tarafından annelerin yenidoğan bakımına ilişkin uygulamalar konusunda bilgilendirilmesi önerilebilir. Primer bakım verici olan hemşire bakımı planlama aşamasında bebek ve ailenin sosyokültürel özelliklerini göz önünde bulundurmalıdır. Ayrınca hemşire yenidoğan bakımı için uygun olmayan girişimlere karşın anne ile çatışmak yerine, yenidoğan bakımına yönelik rehberlik etmelidir. Ailenin inandığı ve uyguladığı geleneksel yöntemleri bilmeli ve sağlığa zarar verebilecek türdeki geleneksel uygulamaları ve bunların getireceği riskleri azaltabilmek için uygun sağıık eğitimleri planlanmalıdır.

Teşekkür: Veri toplama aşamasındaki desteklerinden dolayı Burcu Sağlam, Fatmanur Şener, Merve Akkaya'ya teşekkür ederiz.

6. Eğri G, Gölbaşı Z. 15-49 Yaş Grubu Evli Kadınların Doğum Sonu Dönemde Bebek Bakımına Yönelik Geleneksel Uygulamaları. TSK Koruyucu Hekimlik Bülteni 2007; 6:313-20.

7. Şenol V, Ünalan D, Çetinkaya F, Öztürk Y. Kayseri İlinde Halk Ebeliği ile İlgili Geleneksel Uygulamalar. Klinik Gelişim 2004; 17:47- 55.

8. Şenses $M$, Yıldızoğlu İ. Sekiz ayrı ildeki kaynana ve gelinlerin loğusalık ve çocuk bakımında geleneksel uygulamaları. Çocuk Forumu 2002;5:44-8.

9. Özyazıcıoğlu N, Polat S. 12 Aylık Çocuğu Olan Annelerin Çocuk Bakımına İlişkin Başvurdukları Geleneksel Uygulamalar. Atatürk Üniversitesi Hemşirelik Yüksekokulu Dergisi 2004; 7:63-71. http:// dergipark.gov.tr/download/article-file/29227

10. Biltekin Ö, Boran D, Denkli MD, Yalçınkaya S. Naldöken Sağlık Bölgesinde 0-11 Aylık Bebeği Olan Annelerin Doğum Öncesi Dönem ve Bebek Bakımında Geleneksel Uygulamaları. STED 2004; 13:166-8.

11. Bölükbaş N, Erbil N, Altunbaş H, Arslan Z. 0-12 Aylık Bebeği Olan Annelerin Çocuk Bakımında Başvurdukları Geleneksel Uygulamalar. Uluslararası İnsan Bilimleri Dergisi 2009; 6:164-76. 
12. Çalışkan Z, Bayat M. Annelerin Bebek Bakımı Uygulamaları ve Etkileyen Faktörler: Bir Kapadokya Örneği. Anadolu Hemşirelik ve Sağlık Bilimleri Dergisi 2011;14:23-30.

13. Sis Çelik, A, Çapık A, Engin R. Erzurum'da Gebelik ve Doğum Sonu Dönemde Yapılan Geleneksel Uygulamaların Belirlenmesi. Anadolu Hemşirelik ve Sağlık Bilimleri Dergisi 2012;15:262-7.

14. Sülü Uğurlu E, Başbakkal Z, Dayılar H, Çoban V, Zeynep A. Ödemişte Bulunan Annelerin Bebek Bakımında Uyguladıkları Geleneksel Yöntemlerin İncelenmesi. Gümüşhane Üniversitesi Sağlık Bilimleri Dergisi 2013; 2:342-60.

15. Yalçın H. Gebelik, Doğum, Lohusalık ve Bebek Bakımına İlişkin Geleneksel Uygulamalar (Karaman Örneği). Çocuk Sağlığı ve Hastalıkları Dergisi 2012; 55:19-31.

16. Çınar ï̈, Aslan GK, Kartal A, İnci FH, Koştu N. Annelerin 0-1 yaş Bebek Bakımında Uyguladıkları Geleneksel Yöntemlerin Incelenmesi. TAF Preventive Medicine Bulletin 2015; 14:378-86. [CrossRef]

17. Macdonald NE. The Practice of Traditional Rituals and Customs in Newborns by Mothers in Selected Villages in Southwest Uganda. Paediatr Child Health 2014;19:72.

18. Törüner EK, Büyükgönenç L. Çocuk Sağlığı Temel Hemşirelik Yaklaşımları. 1. Baskı. Cilt 1. Ankara: Göktuğ Yayıncılık; 2011.

19. Cetişli NE, Muslu GK, Şen S, Güneri SE, Bolışık B, Saruhan A. Ege Bölgesinde Doğum Sonu Dönemde Uygulanan Geleneksel Uygulamalar. Uluslararası Hakemli Hemşirelik Araştırmaları Dergisi 2014; 1:22-35. [CrossRef]
20. Işık T, Akçınar M, Kadıoğlu S. Mersin İlinde Gebelik, Doğum ve Lohusalık Dönemlerinde Anneye ve Yenidoğana Yönelik Geleneksel Uygulamalar, Uluslararası İnsan Bilimleri Dergisi 2010; 7:63-84.

21. Sivri BB, Karataş N. Toplumun Kültürel Yönü: Doğum Sonu Dönemde Anne ve Bebek Bakımına Yönelik Yapılan Geleneksel Uygulamalar ve Dünyadan Örnekler. Güncel Pediatri 2015; 13:189-93.

22. Laf̧̧ı D, Erdem E. 15-49 Yaş Grubu Evli Kadınların Doğum Sonu Dönemde Anne ve Bebek Bakımına Yönelik Geleneksel Uygulamaları. Gaziantep Medicine Journal 2014; 20: 226-36. [CrossRef]

23. Özsoy SA, Katabi VA. Comparison of Traditional Practices Used in Pregnancy, Labourand the Postpartum Period Among Women in Turkey and Iran. Midwifery 2008; 24:291-300. [CrossRef]

24. Kahriman İ. Trabzon II Merkezinde 6-12 Aylık Çocuğu Olan Annelerin Bebek Bakımına İlişkin Geleneksel Uygulamaları. Karadeniz Teknik Üniversitesi, Sağlık Bilimleri Enstitüsü, Yüksek Lisans Tezi, Trabzon; 2007.

25. Karabulutlu Ö. Kars Illinde Gebelik ve Doğum Sonu Dönemde Anne Bakımına Yönelik Yapılan Geleneksel Uygulamalar. DEUHYO ED 2014; 7:295-302

26. Gölcük Y. 0-12 Ay Çocuğu Olan Annelerin Bebek Bakımında Başvurdukları Geleneksel Uygulamalar. İnönü Üniversitesi Sağlık Bilimleri Enstitüsü, Yüksek Lisans Bitirme Projesi, Malatya; 2014.

27. Molu B. 0-12 Aylık Bebeği Olan Annelerin Çocuk Bakımında Başvurdukları Geleneksel Uygulamalar, Kocatepe Üniversitesi, Sağlık Bilimleri Enstiütüsü, Yüksek Lisans Tezi, Afyon; 2011. 